\title{
Periphery of Old-Industrial Region Challenged by New Industrialization
}

\author{
Elena B. Dvoryadkina \\ Department of Regional - Municipal Economics and \\ Management \\ Ural State University of Economics \\ Yekaterinburg, Russia \\ elena.dvoryadkina@yandex.ru
}

\author{
Catherine I. Kaibicheva \\ Department of Regional - Municipal Economics and \\ Management \\ Ural State University of Economics \\ Yekaterinburg, Russia \\ Catherine.kai@mail.ru
}

\author{
Irina I. Shurova \\ Department of Business Foreign Languages \\ Ural State University of Economics \\ Yekaterinburg, Russia \\ irina_shurova@mail.ru
}

\begin{abstract}
The article addresses the concepts of an "oldindustrial region", "periphery", "new industrialization", offering a generalized view of some current approaches to the evaluation of processes associated with the new industrialization. Having analyzed the statistical data available, the authors describe a process of the new industrialization occurring in one of old industrial regions of Russia (the Sverdlovsk oblast) and its periphery. It is assumed that, despite the de-industrialization of the 1990s, the industrial sector remains crucial for the economy of the RF subject concerned, including its peripheral municipalities. The improved quality and quantity dynamics of the industry caused by the "new industrialization" is a key to successful development of the region. On its territory, there are several sizeable industrial centers (close to Yekaterinburg, Severouralsk, Nizhny Tagil and Kamensk-Uralsky). Enterprises of these areas ensure most of the industrial production volume in the Sverdlovsk oblast. From 2010 to 2015, the proportion of the peripheral territories in the regionwide indicators was getting down steadily. Judging by the quality indicators referring to the industrial sector, manufacturing enterprises located in the center of the region are driving all the critical innovations, whereas the peripheral territories mostly remain a resource base for the industrial development of the region. The authors conclude that development of old industrial regions and peripheral territories can be ensured by certain center-to-periphery innovation impulses as well as by technological re-equipment of peripheral enterprises, with a transfer of some of them from the center to the periphery.
\end{abstract}

Keywords- Periphery, New Industrialization; Old-Industrial Region, Regional Economy.

\section{INTRODUCTION}

Nowadays, when most of developed countries suffer from a substantial deterioration of the financial position, the issue of the new industrialization has become the forefront of the

The reported study was supported by the Russian Foundation for Basic Research (RFBR), research project No.17-32-00016 "Responses of peripheral urban districts to changes of the parameters of regional economy in conditions of the local government reform". agenda again. The revival of industry in its new capacity, based on the uprise of modern technologies, is at the moment supposed to be something absolutely indispensable or essential for any further development of territories. The leading world powers, which for several years had been reducing the industrial sector by "expatriating" manufacturing enterprises, have regained understanding of necessity to return them large employers, taxpayers - to be drivers for the development of the economy on the whole. Russia is not out of this process either. In this country, the idea of new industrialization has become of vital importance, especially for traditional industrial regions and the peripheral areas attached.

\section{LITERATURE REVIEW}

\section{A. Definition of old-industrial regions}

Old-industrial regions can be considered as territories, with the one-dominant sector of economy (heavy industries, such as coal, steel, heavy engineering, etc.) [1].

The basic features of old-industrial regions are:

- "specialization on products which were basic to other sectors (steel, trains and rail infrastructure, chemical products, electronics), or mass consumption goods (textiles, cars)" [2];

- "early industrialization (compared to other regions in the country)" [3];

- historical over-reliance on a limited group of heavy industries;

- domination of big industrial enterprises.

Exploring Russian old-industrial regions, K.M. Glonti states that "an old-industrial region is an area with the low technology industry and production facilities getting 
obsolete." Further, he notes that, "This is a territory with a relatively low level of technological development of the industrial complex located within its borders, though wellestablished over time. Such territories commonly suffer from severe problems of humanitarian nature (from demography to ecology). Above all, there is a problem of overcapacity of large and medium-sized enterprises, obsolete equipment and out-of date technologies" [4]. On the other hand, the demerits of old-industrial regions, in certain circumstances, might turn into their merits. In fact, the availability of production capacities (including premises, storage facilities, etc.) is often treated as a "low order" competitive advantage. However, many old-industrial regions of Russia enjoy the competitive advantage of the high order, which is the availability of the highly-qualified and relatively cheap (by the Western standards) labor force.

Old-industrial regions occupy a special position in the modern Russian economy. They concentrate on their territory significant industrial capacities of the whole country. In figures, the Sverdlovsk region - one of the old-industrial regions of the Urals - accounts for $85.4 \%$ of drilling rigs manufactured in Russia, $18.7 \%$ of overhead electric cranes, $22.1 \%$ of steel pipes; it produces a tenth of the rolled ferrous metals, pig iron and finished steel.

\section{B. Central and peripheral areas of a territory as part of an old-industrial region economic space}

In economic literature, space is associated with an area, economic activities, information flows between economic agents. In order to determine economic space, some scholars use the concept of "territory". Within the territorial approach, the concepts of "space" and "territory" are often assumed identical. The territorial approach allows one to consider economic space within certain geographic, national and other borders; regions, cities, municipal units, etc., being elements of space. For purposes of this article, let us adhere to the given approach to the treatment of economic space.

Economic space of any level is composed of a center and a periphery. The concepts of "center" and "periphery" are also widely debated in the academic literature.

In the past, many scholars focused on the investigation of center and periphery. They tried to explain what center and periphery is, to identify the factors behind the uneven socioeconomic development of regions. The basic concept is a core-periphery theory suggested by J. Friedmann. According to the scholar the main feature of central areas is high level of autonomy and low level of dependence on other regions. "A center (core) is a region with a high degree of autonomy and the ability to create innovations; it is capable of grasping the central changes (impulses) of development" [5]. According to J. Pénzes "the center means midpoint, central position in space or it represents a space portion which also involves a positive quality in addition to the geometric situation. In a particular spatial system, it refers to the relative central position designated by the quantitative and qualitative characteristics, comparing to other space element" [6].
Therefore, one can speak about a center at the macro(global center), meso- (macro-regions of the world, such as Europe), micro- (national center) levels (Fig. 1).

“ The macro-level: Global and transnational scale

- Position of countries and international groups of countries within the world

- Position of countries or states within continents

- Position of "spatially larger" regions within continents

- The mezzo-level: Regional scale

- Position of regions within countries or states

- Position of micro-regions within "spatially larger" regions

- The micro-level: Local scale

- Position of communities within the regions or microregions

- Position of areas within intra-urban or intra-rural structures" [7 cited 8].

So a country, its parts, a group of countries, regions can be identified as core areas.

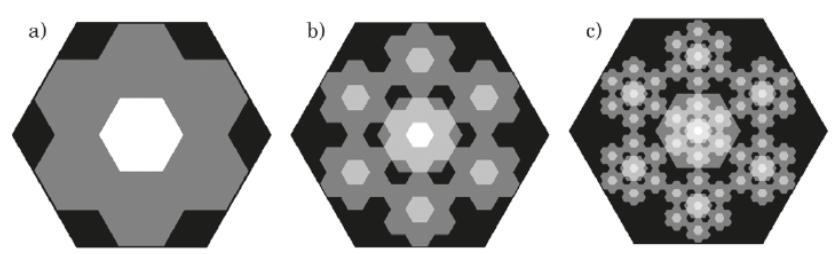

Fig. 1. Spacial distribution center - semi-peripheries - peripheries at the a) macro-; b) meso-, c) micro- levels (theoretical model). [7]

An analysis of the academic literature on the spatial and regional development reveals that there exists an array of views on the nature of "periphery" as well as several approaches to how to define peripheral areas.

The geometric approach. "The central factor in determining the degree of peripherality is, consequently, the distance from the center" [9]. So peripheral areas are countries, regions or settlements with the low degree of transport accessibility, distant from the center.

The ecological approach. "From this point-of-view, the core comprises an area with good environmental conditions, which is little used by humans or entirely unused" [9]. In contrast with this, peripheral areas can be defined as densely populated and considerably transformed or devastated by human activities.

The social approach. This approach focuses on human dimensions, characteristics of social groups, social structure etc. Peripheral are areas where "manifestations including social exclusion, criminality, illegal drug use and others are typically found" [9]. 
The economic approach. It is commonly used. Economic indicators such as GDP per capita, investment rate, etc. are used to identify central and peripheral areas. Center and periphery can be identified as the economic developed and less developed areas.

The political approach. "Territories that are, for whatever reason, beyond the interest of those, who are entrusted with decision making power (e.g. national governments), which brings a series of negative consequences to these areas" [9], can be labelled peripheral.

The innovation approach. The fundamental distinguishing point between core and peripheral areas is their capacity to innovations. A center creates and concentrates innovations. "A periphery is implicitly defined as an area, which has not grasped these changes" [5].

The historical approach. This approach allows one to consider core-periphery relations in dynamics. A center and a periphery are considered in view of a state-constituting process.

In terms of Russia and her space development, some basic approximation allows to identify its specific features. For instance, G.A.Yavlinsky considers the Russian economic system as a "peripheral capitalist economy". "The essence is this: within the framework of this model, capitalism - with all its must-have system-forming properties (private ownership, freedom of enterprise and market-driven behavior of economic entities) operates in the setting of the highly underdeveloped civil society, weak state institutions and dependent position of the country in the system of the global capitalist economy" [10].

As regards old-industrial regions of Russia, central territories are, as a rule, some large industrial centers ranked as administrative subjects of the Russian Federation. By peripheral areas of old-industrial regions the authors mean territories, distant from the administrative center of a region, with a limited economic potential and low level of economic development (in contrast to other parts of the region) [11]. Their main features are obsolete production capacities, high depreciation of fixed assets, relatively low level of wages, industrial specialization, low susceptibility to innovations.

\section{New industrialization: essence of the concept}

Although the term of "new industrialization" was first introduced as early as in the 60s-70s of the XX century, the scientific community has not achieved a single understanding of what it implies. According to Ye.G. Animitsa, Ya.P. Silin, N.V. Novikova, "the concept of the new industrialization is based on the institutions and fundamental principles of the market economy and democratic society; with regard to the achieved level of integration into the global economy, improved efficiency and labor productivity growth. A number of experts from developed countries demonstrate a somewhat different understanding of the concept. Until recently in West Germany, for instance, the idea of the new industrialization was developed in parallel with the conception of the "third industrial revolution" [12].
Within the article, we conceptualize the new industrialization as a renovation of the economy technological base and modification of the ways to run the national economy [13].

\section{NEW INDUSTRIALIZATION IN OLD-INDUSTRIAL REGIONS: PROSPECTS OF DEVELOPMENT}

Large cities are most often regarded as a driving force of the new industrialization processes. Peripheral areas, however, can be considered as its specific resource potential. One should start an analysis of the new industrialization processes in old-industrial regions with the evaluation of industrial development quantitative indices. Most scholars, when considering the processes of new industrialization, focus largely on such indicators that are:

- employed in the economy by economic activity (mining and quarrying; manufacturing; electricity, gas and water supply);

- an industrial producer price index;

- a volume of shipped own produced goods, works performed and services rendered by economic activity (mining and quarrying; manufacturing; electricity, gas and water supply).

Let us consider the processes of the new industrialization, taking, as an example, Sverdlovsk oblast - one of the oldindustrial regions of Russia. Currently, Sverdlovsk oblast's industry presents a powerful diversified industrial complex one of the largest in Russia. In 2015, by the volume of shipped products in the extractive industries the region occupied the 30th place in Russia, processing industries - the 4th, production and distribution of electric energy, gas and water the 6th place.

TABLE I. PROPORTION OF MINING, MANUFACTURING, PROCESSING COMPANIES, ELECTRICITY, GAS AND WATER SUPPLIERS. (KEY SVERDLOVSK REGION ECONOMIC INDICATORS) [14]

\begin{tabular}{|c|c|c|c|c|}
\hline \multirow{2}{*}{$\begin{array}{c}\text { Economic } \\
\text { activities }\end{array}$} & \multicolumn{2}{|c|}{$\begin{array}{c}\text { Gross Regional } \\
\text { Product }\end{array}$} & \multicolumn{2}{c|}{$\begin{array}{c}\text { Average annual } \\
\text { employment in } \\
\text { companies }\end{array}$} \\
\cline { 2 - 5 } & $\mathbf{2 0 0 5}$ & $\mathbf{2 0 1 3}$ & $\mathbf{2 0 0 5}$ & $\mathbf{2 0 1 4}$ \\
\hline $\begin{array}{c}\text { Mining and } \\
\text { quarrying }\end{array}$ & 4.4 & 1.8 & 2.3 & 2.0 \\
\hline Manufacturing & 31.4 & 26.2 & 26.0 & 22.6 \\
\hline $\begin{array}{c}\text { Electricity, gas } \\
\text { and water } \\
\text { supply }\end{array}$ & 3.5 & 3.8 & 3.1 & 4.3 \\
\hline $\begin{array}{c}\text { Others } \\
\text { economic } \\
\text { activities }\end{array}$ & 60.7 & 68.2 & 68.6 & 71.1 \\
\hline
\end{tabular}

The dynamic pattern of the industrial production indices in Sverdlovsk oblast testifies that its industrial enterprises remain a crucial factor for the development of the regional economy on the whole. In 2013, they accounted for $31.8 \%$ of the gross regional product of the RF subject concerned (Table 1). In 2014 , over 11,100 companies were engaged in the industrial production of the region. The average annual employment in 
these enterprises is nearly 450,000 people, which makes a third $(29 \%)$ of the workforce engaged in all the spheres of the regional economy.

Hard times in the development of the regional industry were associated with the turmoil of the 1990s, and later with the global financial crisis of 2008 (Fig. 2).

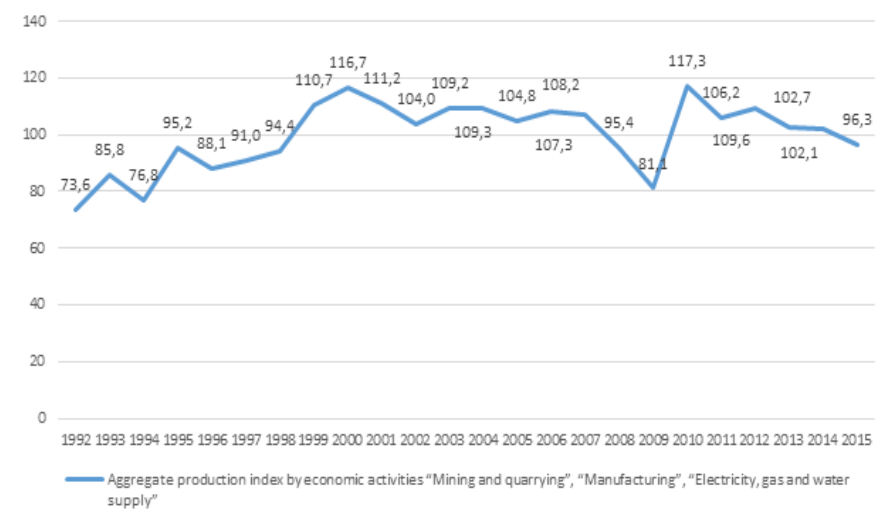

Fig. 2. Aggregate production index in mining and quarrying, manufacturing, electricity, gas and water supply [14]

When analyzing the new industrialization processes in the Sverdlovsk oblast, I.V. Makarova and G.B Korovin highlight the following trends of development: a more intensive innovation and investment activity of industrial enterprises; a shift of the labour force to a higher proportion of university and vocational schools graduates, an increased share of knowledge-intensive and high-tech industries; consolidation of vertical integration in the economy [15].

\section{PATTERN OF NEW INDUSTRIALIZATION IN THE SVERDLOVSK OBLAST}

This section focuses on the spatial concentration of the manufacturing sector in the Sverdlovsk oblast.

As regards the spatial development of industry in the Sverdlovsk oblast, it should be noted that in the region there are several sizeable industrial centers (Fig. 3). The first one is the Ekaterinburg agglomeration with the satellite cities of Berezovsky, Polevskiy, Verhny Pyshma, Asbestos, Pervouralsk, Revda. The second - the so-called northern cluster (Severouralsk, Karpinsk, Krasnoturinsk, Serov). The third one is the Nizhny Tagil hub (Nizhny Tagil, Verkhnaya Salda, Krasnoturinsk). The fourth industrial center is represented by the city of Kamensk-Uralsky.

Calculation of a specialization index, based on formula (1), made it possible to identify economic specialization (list of economic activities) for the municipal units of the Sverdlovsk oblast (Fig. 4). It allows one to conclude that a significant proportion of the peripheral territories retain their industrial specialization. Only a few municipal units of the region, including the administrative center (Ekaterinburg) have a diversified economic structure.

$$
K_{c}=I_{i} / I_{r}
$$

where: Kc - a specialization index; Ii - a proportion of employees with a certain type of economic activity in the imunicipal unit; Ir - the proportion of employees with the same type of economic activity in Sverdlovsk oblast.

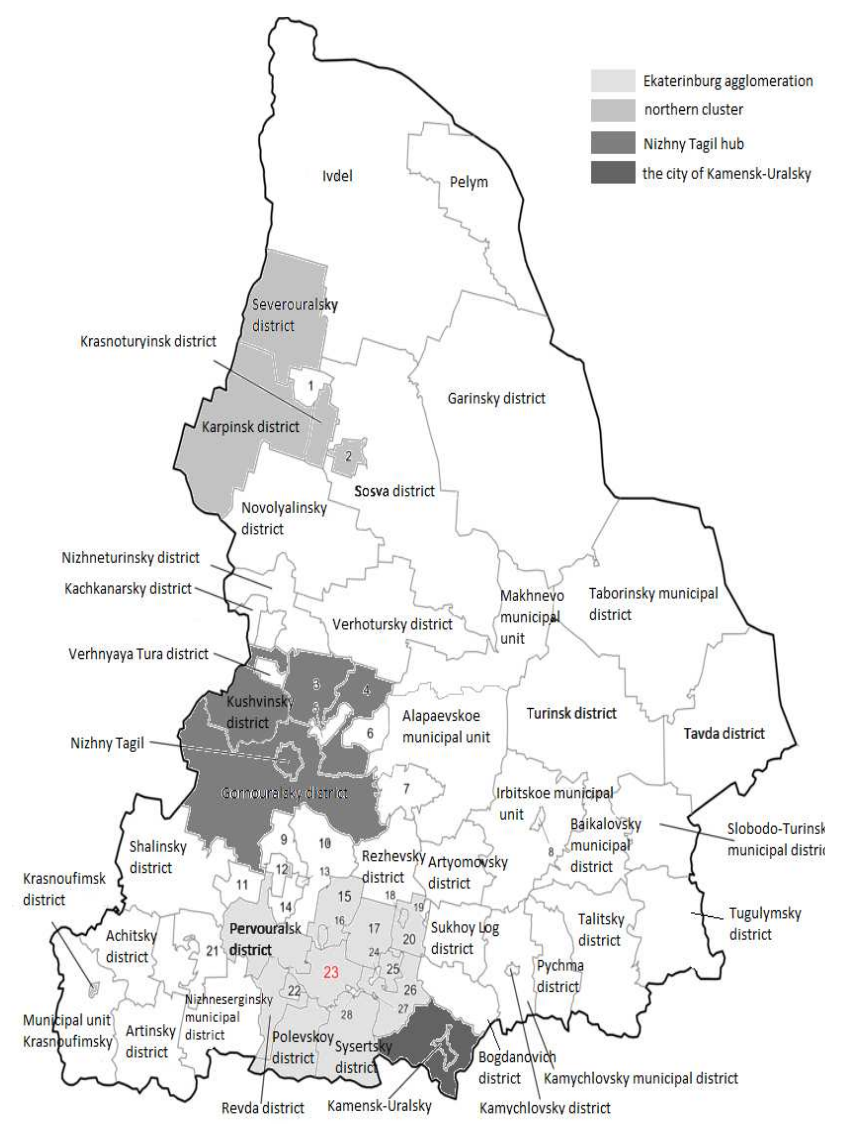

1 - Volchansk district; 2 - Serov district; 3 - Krasnouralsk district; 4 - Verhnesaldinsky district; 5 -Svobodny district; 6 - Nizhnya Salda district; 7 - Alapaevsk district; 8 - Irbit district; 9 Kirovgradsky district; 10 - Nevyansky district; 11 - Staroutkinsk district; 12 - Verhny Tagil district; 13 - Verkh-neyvinsky district; 14 - Novouralsk district; 15 - Verhnya Pyshma district; 16 Sredneuralsk district; 17 - Berezovsky district; 18 - Malyshevsky district; 19 - Reftinsky district; 20 - Asbest district; 21 -Bisertsky district; 22 - Degtyarsk district; 23 - municipal unit "the city of Ekaterinburg"; 24 - Verhnee Dubrovo district; 25 - Zarechny district; 26 - Beloyarsky district; 27 - poselok Uralsky; 28 Aramilsky district

Fig. 3. Industrial centers of the Sverdlovsk oblast 


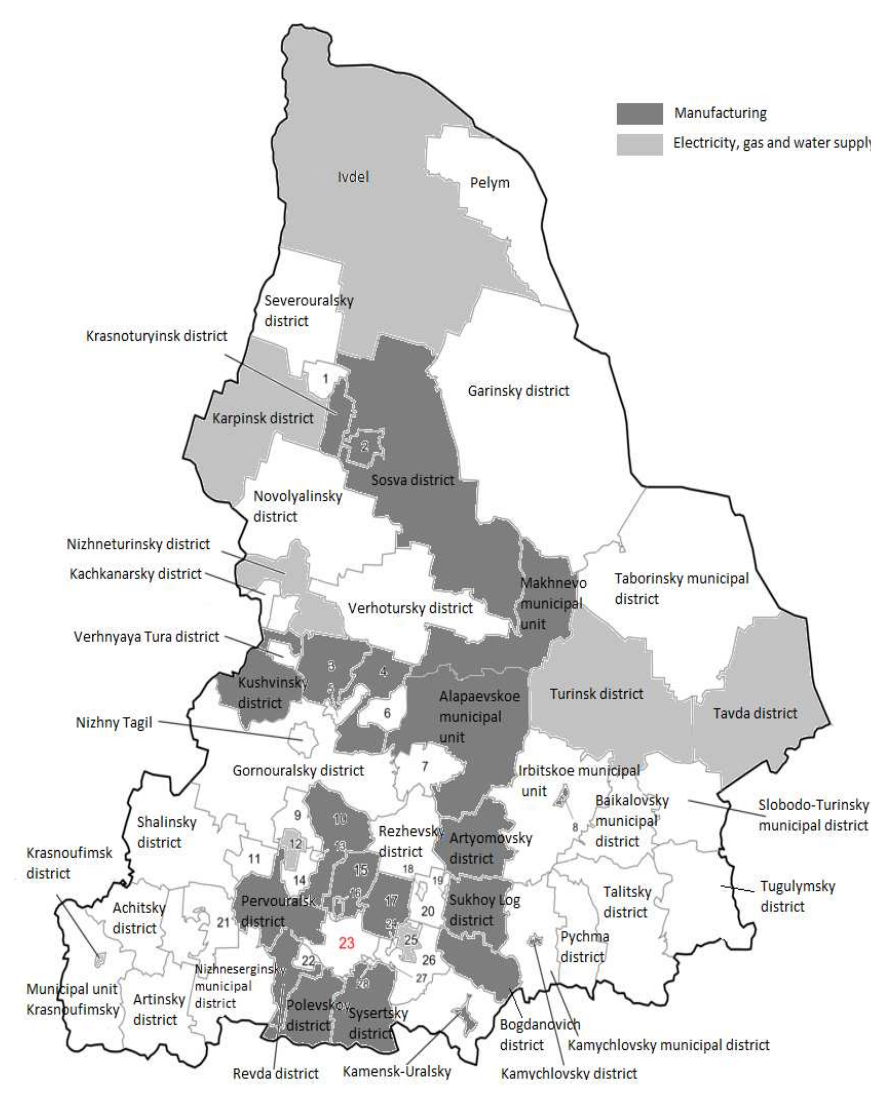

1 - Volchansk district; 2 - Serov district; 3 - Krasnouralsk district; 4 Verhnesaldinsky district; 5 -Svobodny district; 6 - Nizhnya Salda district; 7 - Alapaevsk district; 8 - Irbit district; 9 - Kirovgradsky district; 10 Nevyansky district; 11 - Staroutkinsk district; 12 - Verhny Tagil district; 13 - Verkh-neyvinsky district; 14 - Novouralsk district; 15 - Verhnya Pyshma district; 16 - Sredneuralsk district; 17 - Berezovsky district; 18 Malyshevsky district; 19 - Reftinsky district; 20 - Asbest district; 21 Bisertsky district; 22 - Degtyarsk district; 23 - municipal unit "the city of Ekaterinburg"; 24 - Verhnee Dubrovo district; 25 - Zarechny district; 26 Beloyarsky district; 27 - poselok Uralsky; 28 - Aramilsky district

Fig. 4. Economic specialization (economic activities) of the municipal units of the Sverdlovsk oblast

The share of the periphery in the volume of shipped own produced goods, works performed and services rendered by economic activity (mining and quarrying, manufacturing, electricity, gas and water) tend to decline, with the increased share of the regional center (table 2).

It should be noted that an actual contribution of industrial enterprises - located both centrally and peripherally - into the most essential regional indicators is expected to be higher than the figures given in table 2, as some data required for a more accurate calculation (the volume of shipped/ produced goods, work performed and services in certain enterprises) are not publicly available according to the Russian legislation, (for more details see: Federal Law No. 282-Ф3 of 29/11/07 "On Official Statistical Accounting and State Statistics System in the Russian Federation ").
TABLE II SPECIFIC WEIGHT OF CENTRAL AND PERIPHERAL TERRITORIES IN VOLUME OF SHIPPED OWN PRODUCED GOODS, WORKS PERFORMED AND SERVICES RENDERED BY ECONOMIC ACTIVITY OF THE REGION, \% OF THE TOTAL

\begin{tabular}{|c|c|c|c|c|c|c|}
\hline Code & $\mathbf{2 0 1 0}$ & $\mathbf{2 0 1 1}$ & $\mathbf{2 0 1 2}$ & $\mathbf{2 0 1 3}$ & $\mathbf{2 0 1 4}$ & $\mathbf{2 0 1 5}$ \\
\hline $\begin{array}{c}\text { Mining and } \\
\text { quarrying }\end{array}$ & 1.02 & 0.97 & 1.13 & 1.30 & 1.28 & 1.21 \\
\hline Manufacturing & 17.14 & 17.10 & 16.34 & 18.07 & 17.70 & 21.17 \\
\hline $\begin{array}{c}\text { Electricity, } \\
\text { gas and water } \\
\text { supply }\end{array}$ & 33.48 & 34.19 & 35.88 & 38.50 & 37.60 & 37.07 \\
\hline $\begin{array}{c}\text { Mining and } \\
\text { quarrying }\end{array}$ & 0.00 & 0.00 & 0.00 & 0.00 & 0.00 & 0.00 \\
\hline Manufacturing (Ekaterinburg) & \\
\hline $\begin{array}{c}\text { Electricity, } \\
\text { gas and water } \\
\text { supply }\end{array}$ & 1.32 & 0.06 & 0.02 & 0.10 & 0.01 & 0.01 \\
\hline
\end{tabular}

When analyzing the processes of new industrialization, it is necessary to focus not only on quantitative indicators, but also on qualitative characteristics of industrial development.

By the latter, the authors mean availability and allocation of innovative industrial enterprises throughout the region as well as production operations of the fifth and sixth technological modes, etc. The question arises: what industries can be referred to high-tech industries? What products or services should be ranked as high-tech ones? In the European Union, the two main approaches are assumed to identify technological intensity: the sectoral approach (table 3) and the product approach.

TABLE III. HIGH-TECH SECTORS IN THE EU $[16,17]$

\begin{tabular}{|c|c|}
\hline Code & Economic Activities \\
\hline \multicolumn{2}{|r|}{ High-Tech Manufacturing } \\
\hline 21 & $\begin{array}{l}\text { Manufacture of basic pharmaceutical products and } \\
\text { pharmaceutical preparations }\end{array}$ \\
\hline 26 & Manufacture of computers, electronic and optical products \\
\hline \multicolumn{2}{|r|}{ High-Tech Knowledge Intensive Services } \\
\hline 59 & $\begin{array}{l}\text { Motion picture, video and television programme } \\
\text { production, sound recording and music publishing } \\
\text { activities }\end{array}$ \\
\hline 60 & Programming and broadcasting activities \\
\hline 61 & Telecommunications \\
\hline 62 & Computer programming, consultancy and related activities \\
\hline 63 & Information service activities \\
\hline 72 & Scientific research and development \\
\hline
\end{tabular}

The product approach was designed to complete the sectoral approach, that allows to "define 9 high-tech product groups: aerospace; computers office machines; electronicstelecommunications; pharmaceuticals; scientific instruments; electrical machinery; chemicals; non-electrical machinery; armament" [17].

The Russian and European approaches to identifying a composition of the high-tech industries have very much in common (table 4). 
TABLE IV. LIST OF ECONOMIC ACTIVITIES (HIGH-TECH, MEDIUM-TECH HIGH-END AND KNOWLEDGE-INTENSIVE INDUSTRIES) TO CALCULATE THE INDEX OF "PROPORTION OF HIGH-TECH AND KNOWLEDGE-INTENSIVE INDUSTRIES IN GDP" AGAINST THE INDEX SUGGESTED FOR THE OECD MEMBER COUNTRIES [18]

\begin{tabular}{|c|c|}
\hline Code & Economic Activities \\
\hline \multicolumn{2}{|r|}{ High-Tech Activities } \\
\hline 24.4 & Production of pharmaceuticals \\
\hline 30 & Office equipment and computing tools \\
\hline 32 & $\begin{array}{l}\text { Radio, television and commutation equipment, electronic } \\
\text { components }\end{array}$ \\
\hline 33 & $\begin{array}{l}\text { Medical goods, measurement instruments, control tools, optical } \\
\text { instruments, film- and cine equipment, watches }\end{array}$ \\
\hline 35.3 & Aircraft, including spacecraft \\
\hline \multicolumn{2}{|r|}{ Medium-Tech (high-end) Activities } \\
\hline $\begin{array}{l}24- \\
24.4\end{array}$ & Chemicals, except for pharmaceuticals \\
\hline 29 & Machinery and equipment \\
\hline 31 & Electrical equipment \\
\hline 34 & Motor vehicles, trailers and semi-trailers \\
\hline 35.1 & Shipbuilding, maintenance \\
\hline $\begin{array}{l}35.2+ \\
35.4+ \\
35.5\end{array}$ & $\begin{array}{l}\text { Rrailway rolling stock (railway engines, tram-cars); } \\
\text { motorcycles and bicycles; } \\
\text { other transport vehicles }\end{array}$ \\
\hline \multicolumn{2}{|r|}{ Knowledge-Intensive Activities } \\
\hline 61 & Water transport operation \\
\hline 62 & Air and earth-orbital transport operation \\
\hline 64.2 & Telecommunication activities \\
\hline 72 & Computing-tech \\
\hline 73 & Scientific research and development \\
\hline 74.1 & $\begin{array}{l}\text { Law, accounting and auditing; commercial and management } \\
\text { counseling }\end{array}$ \\
\hline 74.2 & $\begin{array}{l}\text { Architecture, engineering, geological prospecting, geophysical } \\
\text { exploration, cartography, hydrometeorology and other activities } \\
\text { connected with solving technical problems }\end{array}$ \\
\hline 74.5 & Recruitment and staff selection \\
\hline 80 & Education \\
\hline 85 & Helthcare and welfare services \\
\hline
\end{tabular}

In 2016, Sverdlovsk oblast occupied the 19th place in Russia by the proportion of its high-tech and knowledgeintensive industries in the gross regional product. The potential of the region in terms of development of high-tech industries is very high. Sverdlovsk oblast concentrates many research centers (with the Ural branch of the Russian Academy of Sciences at the top of the list), universities and higher schools, innovative companies, whose achievements and inventions are of high practical application for the industrial production. However, it is mainly concentrated in large cities, where numerous scientific and educational institutions, sizeable industrial enterprises are engaged in research and scientific development. In this respect, the periphery remains away from the changes, therefore, its lagging behind is growing. However, certain transmission of new technologies to the peripheral areas can promote technical and technological re-equipment of industrial enterprises there, alongside with the revival of the once-lost industries and uprise of the new ones.

\section{V.CONCLUDING REMARKS}

The on-going processes of the new industrialization in developed countries encourage the transition of industry to new technological principles, and lead to the regained awareness of industrial enterprises as the major driving force for the economic development of territories; historically, oldindustrial regions being the participants of these processes.

The exploration of the new industrialization processes occurring in Sverdlovsk oblast - one of the oldest industrial regions of the Urals - gives evidence that its central areas locate high-tech and innovative production, while the peripheral territories mostly remain a resource base. The development of the latter ones relies on the technological infrastructure and production capacities available. In fact, any further dynamics of the new industrialization on the territory of the old-industrial regions can be ensured by the center-toperiphery innovation impulses, as well as by the technological re-equipment of enterprises located in peripheral areas, turning them into the base of the future development under the new economic conditons.

\section{ACKNOWLEDGMENT}

The reported study was supported by the Russian Foundation for Basic Research (RFBR), research project No.17-32-00016 "Responses of peripheral urban districts to changes of the parameters of regional economy in conditions of the local government reform"

\section{References}

[1] C. Beatty, S. Fothergill, and R. Powell, "Twenty Years On: Has the Economy of the UK Coalfields Recovered?", Regional Studies Association International Conference, University of Aalborg: Denmark, vol.39, pp 1654-1675, 2005.

[2] K. Skokan, "Regional Clusters and Transformation of Old Industrial Regions," 3rd Central European Conference in Regional Science CERS, 2009, pp. 770-783.

[3] W. Jaroń, M. Wojciechowski, and S. Zielonka, "Training and Guidance Module for Local Coal Conversion in Enlarging Europe," unpublished.

[4] K.M. Glonti, "Old-Industrial Regions: Problems and Prospects of Development. Problems of Federalism", Regionology, No. 4, pp. 27-39, 2008.

[5] T. Havlíček, P. Chromý, "Contribution to the Theory of Polarized Development of a Territory, with Special Attention Paid to Peripheral Regions," in Geografie, vol. 106, pp. 1-11, 2001.

[6] J. Pénzes, "The Dimensions of Peripheral Areas and their Restructuring in Central Europe," Hungarian Geographical Bulletin, vol. 62 (4), pp. 373-386, 2013.

[7] M. Halás, "Modelling of Spatial Organization and the Dichotomy of Centre - Periphery," Geografie, 119, No. 4, pp. 384-405, 2014.

[8] L. Novotný, M. Mazur, T. Egedy, "Definition and Delimitation of Peripheries of Visegrad Countries," Studia Obszarów Wiejskich, vol. 39, pp. 35-48, 2015.

[9] J. Pileček, V. Jančák, "Theoretical and methodological aspects of the identification and delimitation of peripheral areas," ActaUniversitatisCarolinae, Geographica, vol. 46, No 1, pp. 43-52, 2011.

[10] G.A.Yavlinsky, "Economic Strategy for the Peripheral System," National Research University Higher School of Economics, vol. 2(26), pp. 173-178, 2015. 
[11] E.B. Dvoryadkina, C.I. Kaibicheva, and I.I. Shurova, "Compression of Economic Space and its Impact on Peripheral Areas," International Journal of Economics and Financial Issues, vol. 6, Special Issue (S8), pp. 24-29, 2016.

[12] Ya. P. Silin, Ye. G. Animitsa, N. V. Novikova, "New Normal in Russian Economy: Regional Specificity," Economy of Region, vol. 12, issue 3, pp. 714-725, 2016.

[13] A.I. Tatarkin, O.A Romanova., N.Ju. Buhvalov, "New Industrialization of the Russian Economy," Bulletin of Ural Federal University. Series of Economics and Management, no. 3, pp. 13-21, 2014.

[14] Local Agency of the Federal State Statistics Service in Sverdlovsk Oblast, "Sverdlovsk Oblast Over 80 Years" (Data Book), Ekaterinburg: Federal State Statistics Service Publ., 2015.
[15] I.V. Makarova, G.B. Korovin, "Economic trends of neo-industrialization of the old industrial regions," Regional economics, vol. 12, Issue 31, pp.2-13, 2014.

[16] Eurosat, Statistical Classification of Economic Activities in the European Community, Rev. 2. Luxembourg, Office for Official Publications of the European Communities, 2008.

[17] Eurosat, Science, Technology and Innovation in Europe. Luxembourg, Publications Office of the European Union, 2013.

[18] On Methodology of Calculating the Indices: "Proportion of Production of High-Tech and Knowledge-Intensive Industries in GDP" and "Proportion of Production of High-Tech and Knowledge-Intensive Industries in Gross Regional Product for an RF subject": administrative order by Rosstart (Russian Federal State Statistics Service) of 14/01/14, No. 21. 